\title{
Procurement Mechanism of Goods and Regional Government Services in Accordance with the Principle of Good Governance in Banjarbaru
}

\author{
A.T. Sompa \\ Lambung Mangkurat University \\ 219, Banjarmasin, Indonesia
}

\begin{abstract}
The procurement of goods and services by the regional government is part of the principle of regional autonomy implementation. However, one should be aware that the practice of regional autonomy is vulnerable to abuse of authority. Thus, it is necessary to implement the principle of Good Governance in order to establish the limits of authority. The article aims at describing the mechanism of procurement of goods and services by local governments in accordance with the standards of good governance. A qualitative approach is used in the research. Data collection is conducted in three steps, namely: observation, interview, and documentation. The Miles and Huberman model of data analysis is used in order to achieve accuracy of information in the presentation of narrative texts. The author carries out the data validity test by means of careful and continuous observation, as well as triangulation. The research shows that the regional government in the face of the Banjarbaru City Procurement Services Unit (ULP) has generally been abiding by the principle of Good Governance in terms of transparency, accountability, efficiency and effectiveness (stipulated in Presidential Regulation No. 54 of 2010 and its amendments). However, several obstacles still exist, the main ones being: 1) human resources, which greatly affect the work of the state system, representing the largest risk; 2) the dependence on information technology in the implementation of goods and services procurement, which is carried out using online features (e-procurement); 3 ) the deficiency of budget, needed to guarantee network quality and internet security in Banjarbaru City ULP, 4) incomplete procurement proposal documents.
\end{abstract}

Keywords: Goods/services procurement, regional autonomy, good governance.

\section{Introduction}

The decentralized government system, better known as regional autonomy, is a form of extension of the central government through conferring certain powers to regional authorities. Public organizations, acting as government stakeholders, should ideally be sensitive to public interests [1]. Administrative institutions, in turn, should implement their duties and functions without exceeding the limits of

(C) Sompa A.T., 2019.

(i) This work is licensed under a Creative Commons Attribution 4.0 International License https://creativecommons.org/licenses/by/4.0/ 
authority, which will create an efficient and effective, transparent and accountable form of public service [2].

The research "Governance, Good Governance and Global Governance: Conceptual and Actual Challenges", defines Good Governance as the implementation of state power with an accountable and clean government providing good public services. Good governance is committed to effective cooperation between all parties in order to achieve integrity, professionalism and high standards of working ethics. The public service based on the concept of good governance is believed to be able to maintain people's trust and prevent the government from exceeding the limits of its power [3]. Properly implemented good governance is the main prerequisite for achieving the goals and aspirations of the nation and state. Good Governance, carried out jointly by a trustworthy and transparent government and public organizations, emphasizes equality between state institutions at the central and regional levels, the private sector, and civil society [4].

As far as legal framework goes, the principles of Good Governance in regards to national procurement policy are outlined in Presidential Decree No. 80 of 2003 (which formulates Guidelines for the Implementation of Goods / Services Procurement (PBJ) of the Government), the updated Presidential Regulation No. 95 of 2007 (with the revised seventh amendment), the renewed Presidential Regulation No. 54 of 2010 (including Guidelines for Procurement of Goods and Services of Government Agencies) and the latest Presidential Regulation (Perpres) No. 16 of 2018.

The procurement of goods and services (PBJ) by the Banjarbaru City Government is important because it has a direct impact on the efficiency of development performance. Development is carried out by means of various policies, programs, and projects, which, in turn, consist of several parts or activities, including the procurement of goods and services. However, it is noteworthy that the majority of cases handled by the Corruption Eradication Commission (KPK) and the Business Competition Supervisory Commission (KPPU) are cases related to the procurement of government goods and services. TPK case data at KPK are based on the type of case. PBJ is the biggest case after the Bribery case, and from 2000 to 2016 , KPPU received approximately 2,537 reports from the public, of which $73 \%$ were related to the procurement of goods and services ${ }^{1}$.

Banjarbaru City is one of the few local governments that established the Procurement Service Unit: a regional government organization unit established in 2006, whose function is to carry out the selection of goods/service providers within the Banjarbaru City Government. The Procurement Service Unit (ULP) was formed based on the Decree of the Mayor of Banjarbaru No. 113 of 2006. The Unit was established not only due to the fact that this form of procurement organization was mentioned in Presidential Decree No. 80 of 2003, but mostly because the number of human resources that have a procurement certificate is rather lim-

${ }^{1} 2017$ Annual KPK Report. Available from: https://www.kpk.go.id/en/. Accessed: 03.03.2019. 
ited. With the establishment of ULP, the limited workload of the committee can be controlled and monitored. This article aims to describe the PBJ mechanism implemented by local governments through prioritizing the principles of Good Governance with a view to provide information on PBJ practices that have proven to be most successful.

\section{Research methods}

In their research, the authors use the qualitative approach. The selection of data is based on reliable sources describing community life and is carried out through triangulation. The descriptive method is used to interpret the data and analyze phenomena [5]. This type of research method was chosen by the authors because it qualitatively describes the current state of objects based on the data obtained. The qualitative approach is used to examine and understand phenomena experienced by the research subjects, with the researcher being a key instrument. The data analysis is inductive: it provides written description of people or behaviors observed $[6 ; 7]$.

The research subject is an object, element or person analyzed, which pertains to the research variables [5]. The subjects of the current research include: Kepala Service Unit Procurement of Banjarbaru, personnel of the ULP Working Group, PPK, and providers of goods and services. Data collection techniques are based on three aspects: 1) primary data collection through field research, 2) in-depth interviews of the above mentioned subjects, and 3) secondary data collection in the form of documents obtained from the Banjarbaru City ULP.

The Miles and Huberman model was used for the data analysis. Miles and Huberman [8], suggested that the qualitative data analysis should carried out interactively and continuously until the data is complete. The data is considered complete when new information is no longer obtainable. The qualitative data analysis consists of three procedures:

1) Data reduction summarizes the data obtained from a direct contact with people, events and situations during the field research;

2) Data display requires that the data resulting from the reduction should organized, arranged in graphical formats;

3) Conclusion drawing/verification implies verifying initial conclusions and examining their validity.

A data validity test in accordance the three steps of data collection was conducted to verify the completion of the obtained data $[8 ; 9]$.

In this study, the data validity test included: 1) carefully and continuously increasing the diligence of observations and 2) triangulation. Triangulation is a technique used for checking and comparison of existing data and assuring the validity of research through the use of a variety of methods of data collection. Source triangulation is done by checking the obtained data through several sources. The validated data is then described and categorized according to the sources it was obtained from. Researchers then will sort out the same and different 
data for further analysis. The triangulation method involves checking data obtained from the same source with the help of different techniques, for example by conducting observations, interviews, and analyzing documentation. If there are different results, the researcher confirms the source to obtain the data considered correct. Time triangulation implies meeting the respondents repeatedly to ensure the data credibility.

\section{Research results and discussion}

\section{A. Public Services and the Concept of Good Governance}

When speaking about public services it is important to realize that they are inseparable from public interest. Public interest and public services are interrelated. The need for a certain type of public services can also arise in the process of carrying out organizational activities. Accordingly, there exist several definitions of public services [10]. For instance, public services are often defined as a series of activities carried out by the government to meet the needs of the population within its jurisdiction (the citizens).

Public services are sometimes interpreted as an effort to exercise the basic rights of the community and the government's obligation to realize these basic rights $[11 ; 12]$. Another definition describes public services as services provided by the state and state-owned companies to the community to meet their basic needs and create public welfare [13]. The provision of services by the government to the community requires that both parties cooperate. The public is expected to participate in the government's efforts to improve the quality of services, namely by meeting the rules with awareness and respect for public administrators who provide services. When a government agency's efforts are appreciated, it will work responsibly at providing quality services to meet the needs of the community. Public services have five characteristics, namely:

1. Adaptability: a change in the public demands is directly proportional to the services offered.

2. The bargaining position of the public: the more the public is bargaining for a service, the higher is the opportunity to receive the requested service.

3. Market type: this characteristic refers to the number of service providers available and their relationship with the service recipients.

4. Locus of control: this aspect explains who is in control of the transaction (the user or the service provider).

5. The nature of services: the characteristics reflect the dominant interests of service providers or recipients.

Article 1 of Law No. 25 of 2009 concerning Public Services states that public services are activities or series of activities conducted in the framework statutory regulations and aimed at delivering administrative assistance to the public while meeting service needs of every citizen or resident. Public service providers, hereinafter referred to as Organizers, are all state-run institutions, corporations, independent institutions, and other legal entities established under the law for public 
service activities. Public services are certainly oriented towards satisfaction the needs of the public (the community). Therefore, to maintain public service consistency, it is necessary to apply the principles of good governance.

Good Governance is a process that involves the work of a solid and responsible state government. The government conducts public affairs efficiently and effectively by maintaining the synergy of constructive interaction between the domains of the state, the private sector, and society (society) [14]. Good Governance requires that anyone involved in decision making, be it the government, the private sector or the community, must be accountable to the public, as well as to stakeholder institutions. Moreover, institutions' governance should be efficient and effective in regards to carrying out their functions while being responsive to the needs of society and providing controlling facilities and opportunities for implementing the existing laws and regulations [15-17]. The key to understanding Good Governance is analyzing its main principles, which set a benchmark for the quality of the government's performance.

\section{B. The Principles of Good Governance (Transparency, Accountability, Efficiency, and Effectiveness) in the Procurement of Goods and Services}

Good Governance is understood as implementation of a solid and responsible development management that is in line with the principles of democracy and an efficient market, which include avoidance of misallocation of investment funds and prevention of corruption, both politically and administratively, carrying out budgetary discipline, as well as creation of legal and political framework for the growth of business activity. Good governance as a concept refers to the process of making and implementing decisions with shared responsibility: a consensus reached by the government, citizens and the private sector in regards to the public administration in the country. Analyzing the fundamental principles of good governance will help to get a better understanding of this concept. Proper implementation of these principles serves a way of measuring the performance of a government. The concept of good governance is based on the principles of transparency, accountability, efficiency, and effectiveness.

\section{Transparency Principle}

Transparency means providing information on all the decisions made in the process of administration to the public. The public is not only informed about providers of public services, but also knows the assessment criteria that are used in the selection of providers, including technical requirements for procurement administration, evaluation procedures, evaluation results, and prospective goods/services providers. According to the data provided by district election committees (PPK), the procurement of goods and services in the Banjarbaru City Government has been running quite optimally through the established work units: its transparency is supported by complete documentation about the procurement process of government goods and services that can be accessed online. 
The implementation of Government Goods / Services Procurement is electronically regulated in Presidential Regulation No. 54 of 2010 in conjunction with Presidential Regulation No. 70 of 2012 concerning Procurement of Government Goods / Services. As is stipulated in article 131 paragraph (1), in 2012, K / L / D / I are obliged to carry out the Procurement of Goods / Services electronically for some / all work packages. In addition, Presidential Regulation No. 54 of 2010 jointly with Perpres No. 70 of 2012, which regulate Electronic Procurement Services (LPSE), obliged K / L / D / I work units to administer an electronic Goods / Services Procurement service system, whose operational technical provisions are governed by the Head of LKPP (Regulation No. 2 of 2010 concerning Electronic Procurement Services). In managing the system of procurement of goods/services electronically, LPSE must meet the provisions specified in Act No. 11 of 2008 concerning Electronic Information and Transactions.

Moreover, the electronic monitoring of government goods/services procurement implemented by the Banjarbaru City Government further enhances and guarantees transparency in the expenditure of state funds, ensures availability of information and equality of business opportunities, and encourages healthy competition and (non-discriminative) realization of justice for all business actors engaged in Government Goods / Services Procurement.

According to the principle of transparency, all goods and services procurement activities can be equitably accessed by all parties through an online system. Such openness of procurement activities to the public indicates that the ULP of Banjarbaru City has been implementing the procurement of goods and services in line with the principles of Good Governance.

\section{Accountability Principle}

Accountability presupposes following the rules and regulations related to the procurement of goods/services and accounting for the success of failure of the process. As was explained by the Head of the ULP of the Banjarbaru City (one of the few regions in Indonesia that established a Procurement Services Unit), ever since its establishment in 2006, all activities carried out by the unit in the process of procurement of goods and services have all been based on the provisions of the applicable laws and regulations. The main reason for the establishment of the ULP by the Banjarbaru City Government, based on Keppres No. 80 of 2003, was the achievement of the objectives of Good Governance.

Ever since the establishment of the ULP, the implementation of goods and services procurement by the Banjarbaru City Government has been compliant with the principles of Good Governance. Tender documents, such as technical specifications, HPS, and contract drafts, are reviewed by the ULP for incompletion or errors. PPK, which receives the Minutes of the Results of the Auction and Determination of the Auction Winner, is able to proceed with the next stage of testing goods and services for quality. Accountability principle includes reporting to both internal and external actors, such as the mayor or the surrounding community. With the report on Execution of Goods and Services Examination, prepared 
by the ULP Secretariat, information regarding the procurement of goods and services carried out by the ULP can be publicly monitored.

Based on Article 111 of Presidential Regulation No. 54 of 2010, LKPP has the authority to carry out development and supervision activities in the procurement of goods/services electronically. According to Government Regulation No. 54 of 2010, Government Internal Supervisory Apparatus, or internal supervisors at other institutions, hereinafter referred to as APIP, is a body that conducts supervision of how an organization fulfills its duties and functions through auditing, reviewing, evaluating, monitoring and other supervisory activities. Furthermore, Article 30 of Government Regulation No. 54 of 2010 states that the party supervising physical work in the field is appointed by the PPK in K / L / D / I and is in charge of the budget, based on a predetermined plan.

\section{Principle of Efficiency}

According to the efficiency principle, the procurement of goods/services must be carried out with minimal possible funds and expenditures needed to achieve the target quality within the stipulated timeframe and without exceeding the allocated budget. The keyword related to this principle is saving, namely saving resources, cutting the budget and streamlining procurement times, taking into account the number of apparatus owned compared to the number of procurement work packages carried out. In 2017, there was a total of 134 procurement packages with a total procurement budget of Rp. 213,131,895,900.00, while in 2018, there was 114 packages with a total procurement budget of Rp. 137,630,103,488.29.

In 2018 , the total return received by the ULP was Rp. 177,655,636,137.00, of the total revenue that had been auctioned at Rp. 177,655,636,137.00, while the total contract value generated was Rp. 157,542,415,028.81. Therefore, the procurement of goods and services carried out by the Banjarbaru City ULP in 2018 produced a budget efficiency of Rp. 20,113,221,108.19. In 2017, the total revenue received by the ULP package was Rp. $213,131,890,900.00$, then the total return of the package completed was auctioned at Rp. 205,209,245,900.00, while the total contract value generated was Rp. 171,221,169,150.00. Accordingly, the procurement of goods and services by the Banjarbaru City ULP in 2018 was implemented with a budget efficiency of Rp. 41,910,721,750.00 and a ceiling efficiency of Rp. $33,888,076,750.00$.

In terms of efficiency, the year 2018 proved to be successful for ULP of Banjarbaru City, as it was able to make savings on the budget spent. However, whether the efficiency in providing goods and services corresponding to quality and quantity standards has been achieved remains to be seen. In the procurement process, it is necessary to supervise all parties participating in the activities. If efficiency is affected by technical and non-technical factors, such as location, availability of raw materials, the price of raw materials, personnel, time, risk, regulations, etc., all the participants of the procurement process should be duly informed to avoid further complications. 


\section{Principle of Effectiveness}

Effective procurement of goods and services can be interpreted as procurement of goods/services that adequately meets the customers' needs and outlined objectives. The keyword of this principle is "right", that is the right quality, quantity, time, place, and price. In accordance the principles of Good Governance, procurement of goods and services by the Banjarbaru City Government ULP in 2017 and 2018 was efficient, however, with regards to providing the adequate quality and quantity of goods and services within the minimum possible use of the budget allocated, the Banjarbaru City Government needs to work more to improve the efficiency of the process.

In compliance with the principle of Good Governance, the procurement of goods and services must be optimized so that the goods and services produced meet the customers' demands and there is no risk. Concerning auction packages that fail, according to the ULP working group, coordination with PPK is immediately carried out. The work packages are to be reviewed (in regards to HPS level, high or unusual specifications) without delay. After the additional review, the work packages will be re-auctioned.

\section{Inhibiting Factors in Implementing Principles of Good Governance in the Procurement of Goods and Services}

The procurement of goods and services in the City of Banjarbaru is still missing certain features to be completely congruous with the principles of Good Governance. Among the factors influencing the performance of ULP are limited resources, such as lack of budget, lack of human resources, and culture of procurement of goods and services. Based on the information obtained from interviews with the Head of ULP, the Banjarbaru City ULP Working Group, and a number of service providers, among the main factors inhibiting successful procurement of goods and services in the City of Banjarbaru are: Human Resources, Technical Difficulties, and Funding Sources.

\section{Human Resources (HR)}

Human resources is an integral part of an organization that wants to achieve efficient and effective program implementation. Human resources is an internal factor in the process of procurement of goods and services. The quantity of human resources greatly influences the process of procurement of goods and services. Because the committee has to focus on several fields rather than one particular area to make the procurement of goods and services successful, extensive personnel training is required, which presents a problem. The number of Pokja members to date is still insufficient, as many of them fail to get certifications, therefore certified employees from other SKPD are being hired, which could potentially hamper the procurement process.

For example, the Chairman of the ULP Working Group found it difficult to coordinate activities directly with the ULP Working Group members because the majority of them were not the ULP Secretariat staff but employees from different SKPDs. Members of the ULP Working Group from other SKPDs also serve as 
procurement officials, thus their workload increases whenever their services are needed at an auction. The result is less than optimal procurement process with delays in provision of goods and services.

\section{Information Technology}

Another problem can be attributed to connectivity problems that sometimes still occur and lead to disruption of the network from the central server. While the Bandwidth is available in a number of infrastructures, it is still very limited and requires improvement. As a good internet network is essential to sustain the implementation of the procurement process (e-procurement uses online features, such as registration, data processing, uploading and downloading procurement documents), the connectivity problem remains one of the major obstacles.

\section{Funding Sources}

Finding a funding source is an effort made by the government to raise funds that will be used as operating costs while managing the process of procurement of goods and services from the APBD. An adequate funding source is necessary to cover the computerization and the internet expenses needed to operate the Banjarbaru City ULP service. Substantial funding support is needed to implement electronic goods and services procurement in ULP Banjarbaru City, as computerized systems and internet services used for e-procurement require a significant amount of money to operate. To provide a smooth access to the Banjarbaru City ULP service (which has proven to be efficient and effective for both users and providers of services), the Banjarbaru City Government has budgeted funds through the APBD for the procurement and maintenance of computers and networks, as well as paying salaries to the Banjarbaru City ULP officers. The Banjarbaru City Government must prepare a budget not only to guarantee network quality and internet security in the Banjarbaru City ULP but also prove the ULP Working Group's qualifications, correctness of specifications, and the quantity of materials offered. All these needs require significant budget augmentation.

\section{Procurement proposal}

Sometimes documents proposed by the PA / KPA / PPK can serve as an inhibiting factor for the procurement process as well. For example, in the following cases:

a. When a proposed work package has not been uploaded to the SiRUP ;

b. When lesson plans and proposed work packages are submitted past deadline, both hardcopy and softcopy;

c. When the documents necessary for submitting the proposed work package are incomplete;

d. When procurement documents are not signed by PPK.

\section{Conclusion}

The procurement of goods and services of the local government represented by the Banjarbaru City Procurement Services Unit (ULP) has proven to be successful in terms of transparency, accountability, efficiency and effectiveness, 
complying with the principles of Good Governance. The legal basis for the work of the Unit was Presidential Regulation No. 54 of 2010 and its subsequent updated versions. The research findings have shown that in terms of transparency, the UPL's work was commendable.

As for the accountability aspect, certain shortcomings were noticed:

1. Auction notifications were not published in the printed media;

2. There are still complaints from the related parties that the announcement of the Procurement Document Addendum was too short and the qualification requirements in the procurement documents were unclear;

3. There have also been complaints from providers regarding the response of the ULP Working Group at the explanation stage and the denials that were delayed and inadequate;

4. Several work packages reviewed by the RPP in regards to technical specifications, HPS and contract drafts were similar to the work packages previously carried out.

Generally, the analysis has demonstrated that, discounting the mentioned flaws, the principle of accountability has been implemented.

According to the research findings, the principles of efficiency and effectiveness have been implemented with optimal results.

Among factors inhibiting the implementation of the principles of Good Governance in the procurement process carried out by the Banjarbaru City Procurement Services Unit (ULP) are: 1) the deficit of human resources; 2) inadequate IT support needed to realize e-procurement (internet network connectivity issues); 3 ) the deficiency of budget needed to guarantee network quality and internet security in the Banjarbaru City ULP, 4) incomplete procurement proposal documents.

\section{References}

[1] Hud N. Otonomi daerah. Yogyakarta: Pustaka Pelajar; 2005 (In Indon.).

[2] Kuncoro M. Otonomi Daerah: Menuju Era Baru Pembangunan Daerah. Jakarta: Erlangga; 2014 (In Indon.).

[3] Weiss T.G. Governance, Good Governance and Global Governance: Conceptual and Actual Challenges. Third World Quarterly. 2000; 795-814.

[4] Cabannes Y., Lipietz B. Revisiting the Democratic Promise of Participatory Budgeting in Light of Competing Political, Good Governance and Technocratic Logics. Environment and Urbanization. 2018; 67-84.

[5] Creswell J.W. Research design: pendekatan kualitatif, kuantitatif, dan mixed. Yogjakarta: PT Pustaka Pelajar; 2010 (In Indon.).

[6] Ibrahim. Metode Penelitian Kualitatif. Bandung: Alfabeta; 2015 (In Indon.).

[7] Sugiyono. Metode Penelitian Kuantitatif Kualitatif dan R\&D. Bandung: Alfabeta; 2014 (In Indon.).

[8] Huberman A., Miles M.B. Analisis Data Kualitatif Terj. Tjejep Rohidi. Jakarta: UI Press; 1992 (In Indon.).

[9] Mulyana D. Metodologi Penelitian Kualitatif: Paradigma Baru Ilmu Komunikasi dan Ilmu Sosial. Bandung: PT Remaja Rosdakarya; 2007 (In Indon.).

[10] Dwiyanto A. Mewujudkan Good governance Melalui Pelayanan. Yogyakarta: Pustaka Pelajar; 2005 (In Indon.). 
[11] Kurniawan J.L., Najib M. Paradigma Kebijakan Pelayanan Publik. Malang: In. Trans; 2008 (In Indon.).

[12] El-Haddadeh R., Weerakkody V., Osmani M., Thakker D., Kapoor K.K. Examining Citizens' Perceived Value of Internet of Things Technologies in Facilitating Public Sector Services Engagement. Government Information Quarterly. 2019: 310-320.

[13] Hanif N. Teori dan Praktik Pemerintahan dalam Otonomi Daerah. Jakarta: Grasindo; 2005 (In Indon.).

[14] LAN (Lembaga Administrasi Negara dan Badan Pengawasan Keuangan dan Pembangunan, Akuntabilitas Dan Good Governance). Jakarta: Lembaga Administrasi Negara dan Badan Pengawas Keuangan dan Pembangunan; 2000 (In Indon.).

[15] Thoha M. Birokrasi dan Politik di Indonesia. Jakarta: Rajawali Press; 2005 (In Indon.).

[16] Gill N.K. Good Governance in India: The Concept and The Practice. Asian Journal of Multidimensional Research (AJMR). 2018; 199-206.

[17] Wibawa F. Kebijaksanaan Negara. Jakarta: Yayasan Obor; 2002 (In Indon.).

Article history:

The article was submitted on 20.04.2019.

The article was accepted on 07.11.2019.

\title{
Механизм закупок товаров и услуг регионального правительства в соответствии с принципом «good governance» в городе Банджарбару
}

\author{
А.T. Сомпа \\ Университет Лампунг Мангкурат \\ 219, Банджарасин, Индонезия
}

\begin{abstract}
Аннотация. Закупка товаров и услуг региональным правительством является частью реализации принципа региональной автономии. Однако следует помнить, что практика региональной автономии уязвима для злоупотреблений властью. Таким образом, для установления пределов полномочий необходимо реализовывать принципы благого управления («good governance»). Целью статьи является описание механизма закупок товаров и услуг органами местного самоуправления в Индонезии в соответствии со стандартами благого управления. В исследовании автор опирается на качественный подход. Сбор данных осуществляется в три этапа, а именно: наблюдение, собеседование и документирование. Модель анализа данных Майлза и Хабермана используется для достижения точности информации в представлении нарративных текстов. Автор проводит проверку достоверности данных путем тщательного и непрерывного наблюдения, а также триангуляции. Исследование показывает, что региональное правительство в лице городского отдела закупок Банджарбару в целом соблюдает принцип благого управления с точки зрения прозрачности, подотчетности, эффективности и результативности (закрепленный в Указе Президента Индонезии № 54 от 2010 г. и поправках к нему). Однако автор отмечает, что все еще существует ряд препятствий реализации принципа «good governance» в стране, основными из которых являются: 1) человеческие ресурсы, которые в значительной степени влияют на работу государственной системы, представляя наибольший риск; 2) зависимость от информацион-
\end{abstract}


ных технологий при осуществлении закупок товаров и услуг, которая осуществляется с использованием онлайн-функций (электронные закупки); 3) дефицит бюджета, необходимого для обеспечения качества сети и безопасности Интернета (на примере отдела закупок города Банджарбару), 4) неполнота документов предложения о закупках.

Ключевые слова: закупки товаров / услуг, региональная автономия, благое управление.

\section{История статьи:}

Статья поступила в редакцию 20.04.2019.

Статья принята к публикации 07.11.2019.

\section{Информация об авторе:}

Анди Тенри Сомпа - кандидат политических наук, преподаватель кафедры государственных исследований Университета Лампунг Мангкурат (Индонезия) (e-mail: tenri@ulm.ac.id).

\section{Information about the author:}

Andi Tenri Sompa - PhD in Government Science, Associate Professor of the Department of Government Science, Lambung Mangkurat University (Indonesia) (e-mail: tenri@ulm.ac.id).

\section{Для цитирования:}

Sompa A.T. Procurement Mechanism of Goods and Regional Government Services in Accordance with the Principle of Good Governance in Banjarbaru // Вестник Российского университета дружбы народов. Серия: Политология. 2019. Т. 21. № 4. C. 706-717. DOI: 10.22363/23131438-2019-21-4-706-717

\section{For citation:}

Sompa A.T. Procurement Mechanism of Goods and Regional Government Services in Accordance with the Principle of Good Governance in Banjarbaru. RUDN Journal of Political Science. 2019; 21 (4): 706-717. DOI: 10.22363/2313-1438-2019-21-4-706-717 